\section{Rheumatoid Pleural Effusion with "R.A. Cells" in the Pleural Fluid}

Brit. med. F., 1967, 2, 814

Granular white cells containing cytoplasmic inclusions may be found in the synovial fluid of many patients with rheumatoid arthritis. First reported by McCarty and by Hollander in Arthritis and Rheumatism (vol. 6, 13-14 June) in 1963, their existence has been confirmed by others (Astorga and Bollet, 1964 ; Zucker-Franklin, 1964 ; Malinin et al., 1964 ; Barnett et al., 1964 ; Bodel and Hollingsworth, 1965, Riddle et al., 1965). The inclusions, which number from 2 to 20 per cell, may be seen in unstained wet preparations of synovial fluid, or can be shown with supravital stains, in particular fat stains such as oil red " $O$." Such cells, when washed and disintegrated, release rheumatoid factor. The presence of these cells is diagnostic only when liberation of rheumatoid factor has been shown, since morphologically similar cells may be seen in conditions other than rheumatoid arthritis. Only when these criteria are fulfilled may they be called "R.A. cells" (Hollander et al., 1965). We wish to report the finding of R.A. cells in the pleural fluid of a patient with rheumatoid arthritis.

\section{CAse Report}

A 51-year-old man presented with severe pains in the shoulders, knees, and feet, prolonged morning stiffness, weakness of grip, and malaise. A diagnosis of rheumatoid arthritis was made on the basis of these symptoms, active arthritis in the lateral metatarsophalangeal joints of the feet, an effusion in the left knee, raised E.S.R. (81 mm. in one hour, Westergren), hypochromic anaemia (Hb $75 \%$ ), positive latex fixation and sheep-cell agglutination tests (D.A.T. 1:256), and radiographic evidence of periosteal reaction on the shaft of the left second metatarsal bone. Electrophoresis of serum protein showed a slight decrease in albumin and an increase in gammaglobulin. Antinuclear factor was absent from the serum. Aspiration of the left knee produced $40 \mathrm{ml}$. of turbid greenish fluid with a protein 'content of $3.9 \mathrm{~g} . / 100 \mathrm{ml}$. Numerous polymorphs were present. At this time inclusion body cells were not specifically sought. Chest $x$-ray examination showed bilateral basal pleural effusions but no other abnormality. On questioning, the patient admitted to a slight cough, but there were no other respiratory symptoms. A Mantoux test $(1: 1,000)$ was negative. Three weeks later the chest $x$-ray film showed an increase in the effusion on the left side, and for this reason the patient was admitted to St. Margaret's Hospital, Epping, for further investigation.

Aspiration of the left pleural cavity gave $50 \mathrm{ml}$. of straw-coloured fluid with a protein concentration of $5.4 \mathrm{~g} . / 100 \mathrm{ml}$., and a very low glucose content $(2 \mathrm{mg} . / 100 \mathrm{ml}$.). No organisms or neoplastic cells were found in the fluid, and culture was sterile. A wet preparation showed numerous polymorphonuclear leucocytes, many of which contained granules. These gave a positive fat stain with Sudan III. The fluid was centrifuged and the cells were washed four times in isotonic saline. After the last wash the deposit was resuspended in the residual saline and repeatedly frozen and thawed to disintegrate the cells. The resulting turbid fluid was centrifuged and the supernatant tested for rheumatoid factor. The latex test was strongly positive and the Rose-Waaler test gave a D.A.T. of $1: 1,280$. Pleural biopsy showed organized fibrin with some infiltration by chronic inflammatory leucocytes; there were no rheumatoid nodules or plasma cells and the picture was reported as being nonspecific.

Clinical progress of his arthritis was satisfactory, management consisting of rest in bed, splinting, maintenance physiotherapy, calcium aspirin $3.6 \mathrm{~g}$., and indomethacin $50 \mathrm{mg}$. daily. Corticosteroid injections were given to actively involved joints. The E.S.R. fell to $30 \mathrm{~mm}$. in one hour and the patient was discharged symptomfree on 27 May 1966. A chest $x$-ray film taken just before discharge showed no apparent diminution in the pleural effusions. One month later a loud friction-rub was audible over the whole of the anterior surface of the left chest and upper part of the right chest.

\section{Comment}

Pleural effusions occurring with or without parenchymatous lung disease are recognized as one systemic manifestation of rheumatoid arthritis (Rubin, 1955 ; Emerson, 1956 ; Horler and Thompson, 1959 ; Carr and Mayne, 1961). They occur much more frequently in males, usually middle-aged with recent or developing joint symptoms. They tend to resolve slowly and persist in spite of aspiration.

The differential diagnosis in a patient with both rheumatoid arthritis and pleural effusion may present difficulties. The pleural fluid has the nonspecific features of an exudate, being pale yellow with a high protein content, and while the glucose concentration may be characteristically low this is not invariably so (Carr and Mayne, 1961). Pleural biopsy may not be diagnostic, since the small nodules sometimes present in the pleura are not often included in a single specimen.

This case suggests that an examination of pleural fluid for R.A. cells constitutes an important additional investigation and, since such effusions may develop as a premonitory feature of rheumatoid arthritis before the occurrence of joint manifestations, it could be a useful routine investigation in all cases of pleural effusion of doubtful origin.

We wish to thank Dr. Marsh for performing the pleural biopsy, Dr. I. M. Tuck for the histological report, and Mr. P. G. Sanders for the biochemistry.

D. S. Carmichael, M.C.Path., Consultant Haematologist.

D. N. Golding, M.D., M.R.C.P.I., D.PHYS.MED., Consultant in Physical Medicine and Rheumatology.

\section{St. Margaret's Hospital.}

Epping, Essex.

\section{REFERENCES}

Astorga, G., and Bollet, A. J. (1964). Arthr. and Rheum., 7, 288. Barnett, E. V., Brienenstock, J., and Bloch, K. J. (1964). Ibid., 7, 726. Bodel, P. T., and Hollingsworth, J. W. (1965). Ibid., 8, 432.

Carr, D. T., and Mayne, J. G. (1961). Ibid., 4, 410.

Emerson, P. A. (1956). Brit. med. F., 1, 428.

Hollander, J. L., McCarty, D. J., and Rawson, A. J. (1965). Bull. rheum. Dis., 16, 382.

Horler, A. R., and Thompson, M. (1959). Ann. intern. Med., 51, 1179.

Malinin, T. I., Pekin, T. J., Zvaifler, N. J., and Bauer, H. (1964). Arthr. and Rheum., 7, 743.

Riddle, J. M., Bluhm, G. B., and Barnhart, M. I. (1965). Ibid., 8, 463. Rubin, E. H. (1955). Amer. 7. Med., 19, 569.

Zucker-Franklin, D. (1964). Arthr. and Rheum., 7, 760. 